International Journal of Medical Sciences

ISSN 1449-1907 www.medsci.org 2007 4(2):72-82

(c) Ivyspring International Publisher. All rights reserved

Review

\title{
Role of Dietary Soy Protein in Obesity
}

\author{
Manuel T. Velasquez ${ }^{1}$ and Sam J. Bhathena ${ }^{1,2}$ \\ 1. Department of Medicine, George Washington University Medical Center, Washington DC, USA \\ 2. Phytonutrients Laboratory, Beltsville Human Nutrition Research Center, Agricultural Research Service, U.S. Department \\ of Agriculture, Beltsville, Maryland, USA
}

Correspondence to: Dr. Sam J. Bhathena, Phytonutrients Laboratory, Beltsville Human Nutrition Center, Bldg. 307-C, Rm 215, Beltsville, MD 20705, USA.

Received: 2006.12.05; Accepted: 2007.02.25; Published: 2007.02.26

Soy protein is an important component of soybeans and provides an abundant source of dietary protein. Among the dietary proteins, soy protein is considered a complete protein in that it contains ample amounts of all the essential amino acids plus several other macronutrients with a nutritional value roughly equivalent to that of animal protein of high biological value. Soy protein is unique among the plant-based proteins because it is associated with isoflavones, a group of compounds with a variety of biological properties that may potentially benefit human health. An increasing body of literature suggests that soy protein and its isoflavones may have a beneficial role in obesity. Several nutritional intervention studies in animals and humans indicate that consumption of soy protein reduces body weight and fat mass in addition to lowering plasma cholesterol and triglycerides. In animal models of obesity, soy protein ingestion limits or reduces body fat accumulation and improves insulin resistance, the hallmark of human obesity. In obese humans, dietary soy protein also reduces body weight and body fat mass in addition to reducing plasma lipids. Several potential mechanisms whereby soy protein may improve insulin resistance and lower body fat and blood lipids are discussed and include a wide spectrum of biochemical and molecular activities that favorably affect fatty acid metabolism and cholesterol homeostasis. The biologic actions of certain constituents of soy protein, particularly conglycinin, soyasaponins, phospholipids, and isoflavones, that relate to obesity are also discussed. In addition, the potential of soy protein in causing food allergy in humans is briefly discussed.

Key words: soy protein, obesity, human studies, animal studies, mechanisms, soy protein allergy

\section{Introduction}

Obesity has become a worldwide epidemic and its prevalence continues to increase at a rapid rate in various populations and across all age groups [1-4]. Obesity poses a major public health challenge since it is a well recognized independent predictor of premature mortality [5,6]. Moreover, it often coexists with other cardiovascular risk factors, namely, diabetes, dyslipidemia, and hypertension, which further add to the burden of cardiovascular disease. The dramatic increase in the occurrence of overweight and obesity over the past several decades is attributed in part to changes in dietary and lifestyle habits, such as rapidly changing diets, increased availability of high-energy foods, and reduced physical activity of peoples in both developed and developing countries [7].

Obesity is a complex metabolic disorder that is thought to result from an imbalance of energy intake and energy expenditure leading to the excess accumulation of fat in various adipose tissues and organs. The development of obesity is associated with hyperinsulinemia, insulin resistance, and abnormalities in lipid metabolism. Insulin resistance is considered the most common underlying abnormality in human obesity and is influenced by genetic and environmental factors, and in particular, changes in diet and physical activity $[8,9]$. Lipid abnormalities associated with obesity include increased overall production of lipids with elevated concentrations of fatty acids, triacylglycerols, and low-density lipoproteins (LDL), as well as very-low density lipoproteins (VLDL). Excess sugar intake especially in the form of high sugar containing and high fructose corn syrup containing colas leads to the formation and deposition of lipids in various fatty tissues. Elevated plasma concentrations of free fatty acids (FFA) have been shown to play a key role in contributing to the development of insulin resistance in obesity and in type 2 diabetes mellitus [10]. In addition, there is evidence that suggests that accumulation of excess fat and FFAs in non-adipose tissues, such as the liver, heart, skeletal muscle, kidneys, and blood vessels may impair their functions, and contribute to cell dysfunction or cell death, a phenomenon known as lipotoxicity [11-13]. Preventive or therapeutic strategies to control obesity should target these abnormalities. Various dietary modifications designed to control excess body weight and dyslipidemia have focused on the manipulation of the amount and nature dietary energy and fat intakes. In recent years, increased attention has shifted toward the role of dietary protein intake in the management of obesity. 


\section{Dietary protein and effects on food intake and body weight}

Ingestion of foods with high protein content is well known to suppress appetite and food intake in humans [14]. Among the three macronutrients (carbohydrate, fat, and protein), protein has the most suppressing effect on food intake. In addition, dietary protein has been shown to induce higher satiating and thermogenic effects and greater weight loss than carbohydrates [15-17]. In a randomized trial in overweight and obese subjects, consumption of high protein (25\% of total energy) in ad libitum fat-reduced diets for 6 months produced greater weight loss and body fat loss, compared to consumption of high carbohydrate (12\% of total energy) [15]. These effects were not related to changes in fat intake since the amount of dietary fat ( $30 \%$ of total energy) was maintained constant during the intervention. Similarly, in a 4-week randomized dietary intervention trial of male obese hyperinsulinemic subjects, a high protein hypoenergetic diet $(45 \%$ protein, $25 \%$ carbohydrates, and $30 \%$ fat) also induced greater weight loss and resting energy expenditure, compared to a high carbohydrate hypoenergetic diet $(12 \%$ protein, $25 \%$ carbohydrates, and $30 \%$ fat) [16]. In a recent 12 -week trial conducted in healthy adult subjects, increasing the amount of dietary protein content from $15 \%$ to $30 \%$ of total energy while maintaining the carbohydrate content ( $50 \%$ of total daily caloric intake) in the diet resulted in sustained losses in weight and body fat [17]. The favorable effects on body composition in this study appear to be due to sustained decrease in appetite and ad libitum caloric intake induced by the high-protein intake. More recently, Batterham et al examined the effects of dietary protein on satiety and the responses of gut hormones, particularly the gut hormone peptide YY (PYY), a known inhibitor of food intake in humans and rodents [18]. These investigators showed that high-protein intake induced an increase in plasma PYY levels and marked satiety in normal-weight and obese human subjects. Furthermore, in studies of obese Pyy null mice, which were selectively resistant to the satiating and weight-reducing effects of protein, exogenous administration of PYY in these animals reversed their obesity. These findings suggest that modulating the release of endogenous satiety factors, such as PYY treatment, plays an important role in mediating the satiating effects of dietary protein.

The source or type of dietary protein also has been shown to have an influence on the magnitude of food intake suppression and energy expenditure, as well as on insulin sensitivity [19-22]. Hurley et al. [19] examined the metabolic effects of varying dietary protein and carbohydrate source in rats. These investigators fed male Sprague-Dawley rats for 28 days with semi-purified diets that varied in both protein and carbohydrate sources, namely, soy protein isolate (SPI)-cornstarch, SPI-sucrose, cod protein (COD)-cornstarch, COD-sucrose, casein-
(CAS)-cornstarch, CAS-sucrose. Rats fed SPI-cornstarch showed lower total body energy and fat gains compared with animals fed with the other diet combinations of either, CAS-cornstarch, CAS-sucrose, or SPI-sucrose. Plasma glucose and insulin concentrations were also significantly lower in SPI-cornstarch diet than in those fed the CAS-sucrose diet. The reducing effect of SPI-cornstarch diet on body fat gain may be related to reductions in energy intake and in plasma glucose concentrations. Similarly, Lavigne et al evaluated the effects of feeding various types of dietary protein on glucose tolerance and insulin sensitivity in rats [20]. Male Wistar rats were fed isoenergetic diets containing either casein, cod protein, or soy protein for 28 days. Cod protein-fed and soy protein-fed rats showed lower fasting plasma glucose and insulin concentrations compared with casein-fed animals. After an intravenous glucose load $(1.5 \mathrm{ml} / \mathrm{kg}$ body wt of a $85 \%$ glucose in saline), cod protein-fed and soy protein-fed rats also showed lower incremental areas under glucose curves compared with casein-fed animals, suggesting that cod and soy proteins improve glucose tolerance. Additionally, higher glucose disposal rates were observed in cod protein-fed and soy protein-fed rats as compared with casein-fed rats, indicating an improvement in peripheral insulin sensitivity. However, in the postprandial state, the lower plasma insulin concentrations observed in cod protein-fed and soy protein-fed animals may be due to decreased pancreatic insulin release and/or increased hepatic insulin removal. Recently, Davis et al evaluated effects of casein and soy protein on body weight, plasma cholesterol, and insulin sensitivity in male lean SHHF $(+/ c p)$ rats, a unique rodent model that exhibits the early features resembling the metabolic syndrome in humans [21]. Rats fed soy protein (with either low or high isoflavone content) for 36 weeks had significantly lower body weight, liver weight, total plasma cholesterol, fasting blood glucose, and plasma insulin, compared to rats fed casein.

In a short-term study in humans, Anderson et al have shown that whey protein has a greater suppressive effect on food intake than soy protein or egg albumin [22]. These results differ from those obtained by Lang and co-workers [23] in their studies which compared the effects of six different proteins (egg albumin, casein, gelatin, soy protein, pea protein, and wheat glutein) in a mixed meal on satiety in healthy human subjects. In this study, food intake and satiety was evaluated at 8- and 24-hour post-meal. These investigators found no differences between the different proteins on satiety and 24-hour energy or macronutrient intakes or on post-prandial glucose and insulin concentration. The reasons for these discrepant results are not clear. But they may relate to differences in the experimental design, other macronutrient composition of the diets, and duration of the dietary intervention. Nonetheless, the weight of the evidence suggests that consumption of plant-based protein, particularly soy protein, may suppress food intake and increase satiety and/or energy expenditure that may reduce body fat 
gain and result in weight reduction, effects that may be useful for the prevention and treatment of obesity.

\section{Nutrient composition of soy protein}

Soybeans provide one of the most abundant plant sources of dietary protein. The protein content of soybeans varies from $36 \%$ to $56 \%$ [24-27]. Protein content of soybean from different areas are quantitatively different with those grown in the southern United States having high concentration of crude protein [24]. Differences in crude protein and amino acid composition of soybeans exist both within and among countries [25]. The predominant proteins in soybean are the storage proteins, namely 7S globulin (conglycinin) and 115 globulin (glycinin), which comprise approximately $80 \%$ of the total proteins [26]. Other storage proteins are 2S, 9S, and 15S, which are present in much lesser amounts in soy protein. In addition, soybean also contains lectin and protease inhibitors such as Kuntz and Bowman Burk [27].

Soy protein is considered a complete protein in that it contains most of the essential amino acids that are found in animal proteins. The nutritional value of soy protein is roughly equivalent to that of animal protein of high biological value [28]. For example, isolated soy protein has a protein digestibility-corrected amino acid score of 1.0, which is the same as that of casein and egg protein [28]. However, soy proteins contain low methionine/glycine and lysine/arginine ratios compared to casein [29].

Soy protein is also associated with fatty acids, saponins, isoflavones and phospholipids. On a weight/weight basis, fatty acids comprise the largest group of chemicals in the soy protein isolate (SPI) followed by saponins and then isoflavones. Although phospholipids are incorporated primarily in soybean oil, these compounds are present in smaller amounts in soy protein. SPI contains mainly lysophospholipids, the two major ones being lysophosphatidylcholines and lysophosphatidylethanolamines [30]. Soyasaponins are one of the major classes of phytochemicals present in soy. The primary saponins found in soybeans are group $A$ and group $B$ soyasaponins with their precursors or aglycones, soyasapogenols A and B, respectively. The content of group B soyasaponins in whole soybean seeds is about four fold higher than group A saponins [31]. Saponin content in different varieties of soybeans range from 13-42 $\mu \mathrm{mol} / \mathrm{g}$ in the germ and from 3-6 $\mu \mathrm{mol} / \mathrm{g}$ in the cotyledon [32].

Soy protein is unique among the plant-based proteins in that it is the only plant protein that contains the largest concentrations of isoflavones. The amount of isoflavones in soybeans varies depending upon the type of soybean, geographic area of cultivation, and harvest years of soybeans [33-36]. In addition, isoflavone contents in different soy products also vary substantially due to differences in methods of processing [34]. Soybeans and commercially available soy products contain approximately $0.1-5 \mathrm{mg}$ isoflavones/g protein; one serving of traditional soy foods provides about $0.25-40 \mathrm{mg}$ isoflavones [33,36]. Soy products that contain most of the bean, such as mature soybeans, roasted soybeans, soy flour, and textured soy protein provide the highest concentrations of isoflavones, $0.1-5 \mathrm{mg}$ total isoflavones/g soy protein [35]. Isolated soy protein and other soy protein products, such as tofu and soy milk, provide about 0.1-2 $\mathrm{mg}$ isoflavones/g soy protein. Green soybeans and tempeh are intermediate sources of isoflavones, providing about $0.3 \mathrm{mg} / \mathrm{g}$ soy protein. Alcohol-extracted products, such as soy protein concentrate, contain relatively much lower amounts with values of $\leq 0.3$ $\mathrm{mg}$ isoflavones/g soy protein.

\section{Effect of dietary soy protein in animals and humans with obesity}

A number of studies in animals and humans suggest that consumption of soy protein have favorable effects on obesity and lipid metabolism.

\section{Animal Studies}

The studies on the effect of soy protein in animal models of obesity are summarized in Table 1. Iritani and co-workers [37] studied the effects of dietary soy protein on body weight, plasma and liver triacylglycerol concentrations, and lipogenic enzyme gene expression in livers of genetically obese Wistar fatty rats. Wistar fatty rats and their lean littermates were fed casein or soy protein isolate diet containing hydrogenated fat ( $4 \%$ hydrogenated fat plus $1 \%$ corn oil) or corn oil (5\%) for 3 weeks. After 3 weeks of feeding, the fatty rats fed soy protein had lower body weight than those fed casein. Similarly, plasma and liver triacylglycerol concentrations were also lower in soy protein-fed fatty and lean rats than in those fed casein. Moreover, the hepatic messenger RNA concentrations and activities of lipogenic enzymes were found to be lower in rats fed soy protein than in those fed casein, regardless of genotype or dietary fat. Using the same rodent model, the same group of investigators further examined the effects of different dietary fatty acids and proteins on glucose tolerance and insulin receptor gene expression in male Wistar fatty rats [38]. In this study, obese rats and their lean littermates ( $8 \mathrm{wk}$ old) were fed a casein or soy protein diet containing $9 \%$ partially saturated beef tallow (plus 1\% corn oil), $10 \%$ corn oil or $10 \%$ fish oil for $3 \mathrm{wk}$. In glucose tolerance tests, plasma insulin concentrations were significantly higher in obese rats fed corn oil or fish oil than in those fed partially saturated beef tallow, particularly in the soy protein groups. However, plasma glucose concentrations were not significantly affected by dietary protein or fat. The insulin receptor mRNA concentrations in livers and adipose tissues were higher in rats fed soy protein/partially saturated beef tallow than in those fed any other protein/fat combination. Thus, dietary soy protein appears to have anti-obesity effects and may also reduce insulin resistance, but only when a diet low in polyunsaturated fatty acids is consumed. 
Table 1. Effects of dietary soy protein in animal models of obesity.

\begin{tabular}{|c|c|}
\hline Model & Diet and Amount \\
\hline Obese Wistar fatty rats & soybean protein isolate vs casein \\
\hline Male Wistar fatty rats & Soybean protein isolate vs casein \\
\hline $\begin{array}{c}\text { Dietary obese male Spra- } \\
\text { gue-Dawley rats and Obese } \\
\text { yellow KK mice }\end{array}$ & $\begin{array}{c}\text { Soy protein isolate and hydrolysate } \\
\text { vs casein protein, } 35 \% \text { high-protein, } \\
5 \% \text { low-fat }\end{array}$ \\
\hline Genetically obese mice & $\begin{array}{c}\text { Soy protein isolate and hydrolysate } \\
\text { vs milk whey protein isolate and } \\
\text { hydrolysate }\end{array}$ \\
\hline Obese KK-Ay mice & $\begin{array}{l}\text { Soy protein isolate vs casein protein, } \\
\text { isocaloric } 15 \mathrm{~g}, 100 \mathrm{~g} \text { diet }\end{array}$ \\
\hline Zucker fa/fa rats & $\begin{array}{c}\text { Soybean protein diet isolate vs } \\
\text { casein }\end{array}$ \\
\hline Zucker fa/fa rats & Soybean protein diet vs casein \\
\hline
\end{tabular}

In another study, Aoyama et al compared the effects of an energy-restricted, low-fat (5\%) and high-protein $(35 \%)$ diet with either soy protein isolate (SPI) and its hydrolysate (SPI+H) or casein in male Sprague-Dawley rats made obese by feeding high-fat diets containing $30 \%$ fat and in genetically obese yellow KK mice [39]. They showed that body fat content and plasma glucose levels were significantly lower in mice fed SPI and SPI+H diets than in those fed casein. In rats, plasma total cholesterol level was lower with the $\mathrm{SPI}+\mathrm{H}$ diet than with the casein diet. This study indicates that SPI and SPI $+\mathrm{H}$ are suitable protein sources in energy-restricted diets for the treatment of obesity. SPI and its hydrolysate also decreased body weight and perirenal fat pads compared to whey protein isolate [40].

Nagasawa et al. [41] evaluated the effects of a calorie-restricted diet containing soy protein isolate (SPI) on body fat composition, plasma glucose, lipid and adiponectin levels and expression of genes involved in glucose and fatty acid metabolism in obese male KK-A y mice. Body weights and adipose tissue weights of mesenteric, epididymal, and brown fat were lower in mice on SPI diet. Plasma cholesterol, triglyceride, FFA, and glucose levels were also decreased by the SPI diet. Body fat content and plasma glucose levels in mice on a SPI diet were still lower than those treated with an isocaloric casein protein diet. Among the genes related to glucose and fatty acid metabolism, adiponectin mRNA levels in adipose tissue and adiponectin plasma concentrations were elevated in mice on a calorie-restricted diet, but there were no significant differences between soy protein and casein protein groups. These investigators concluded that that soy protein diet decreased body fat content and plasma glucose levels more effectively than isocaloric casein protein diet in obese mice.

In a longevity study of Zucker obese ( $\mathrm{fa} / \mathrm{fa}$ ) and lean $(\mathrm{Fa} / \mathrm{Fa})$ rats, Johnson et al showed that them feeding a soy protein diet ad libitum from 4 weeks of age remarkably prolonged their survival [42]. Moreover, pair-feeding obese Zucker rats with lean control

\begin{tabular}{|c|c|c|}
\hline Duration & Effects & References \\
\hline $3 \mathrm{wks}$ & $\begin{array}{l}\text { Decreased BW, and plasma and liver } \\
\text { triacylglycerols, decrease activity of li- } \\
\text { pogenic enzymes }\end{array}$ & 36 \\
\hline 3 wks & $\begin{array}{l}\text { Increased insulin receptor mRNA in liver } \\
\text { and adipose tissues, decreased insulin } \\
\text { resistance }\end{array}$ & 37 \\
\hline 2 wks & $\begin{array}{c}\text { Decreased body fat and plasma glucose } \\
\text { in mice }\end{array}$ & 38 \\
\hline \multirow[t]{2}{*}{2 wks } & Decreased BW and perirenal fat & 39 \\
\hline & $\begin{array}{l}\text { Decreased BW, bodyfat content, mesen- } \\
\text { teric, epididymal, and brown fat weight }\end{array}$ & 40 \\
\hline Life-time & $\begin{array}{l}\text { Prevented hyperphagia, prolonged sur- } \\
\text { vival }\end{array}$ & 41 \\
\hline 160 days & $\begin{array}{l}\text { Decreased lipogenesis, decreased } \\
\text { SERBP-1 and FAS }\end{array}$ & 60 \\
\hline
\end{tabular}

rats prevented hyperphagia (with $8-18 \%$ restriction in energy intake) and also increased maximum life span, effects that were seen in both male and female animals. Interestingly, the percentage of body fat in food-restricted obese rats did not differ from that in animals fed ad libitum, suggesting that the protective effect of soy protein is not entirely related to adiposity per se.

\section{Human studies}

Thus far, there have been only limited data regarding the long-term effects of dietary soy protein on obesity in humans (Table 2). In a short-term randomized single-blind study, Mikkelsen and coworkers compared the effects of fat-reduced diets containing either pork-meat protein, soy protein, and carbohydrate on 24-h energy expenditure in 12 young overweight and mildly obese men (body mass index = 26-32) [43]. Diets were isoenergetic: pork diet (29\% of energy as fat and $29 \%$ as protein); soy diet ( $29 \%$ of energy as fat and $28 \%$ as protein); and carbohydrate diet ( $28 \%$ of energy as fat and $11 \%$ as protein) and were administered for 4 days in a 3-way crossover design. After 4 days of each dietary intervention, 24-h energy expenditure measured in a respiratory chamber was significantly higher with the pork or soy diet than the carbohydrate diet. However, the animal protein diet produced a higher 24-h energy expenditure than the soy protein diet. These results indicated that both animal and soy protein have a greater thermogenic effect than carbohydrate, which may be relevant for the prevention and treatment of obesity.

Similarly, Bosello et al evaluated the short- and long-term effects of hypocaloric diets containing proteins from different sources on body weight and plasma lipids in obese subjects [44]. In this study, 24 obese patients, aged $25-42$ yrs, of at least $50 \%$ above ideal weight, were divided into two groups: one group received casein and the other group, soy protein. Both diets were hypocaloric and contained the same amount of protein. The subjects initially received $375 \mathrm{kcal} /$ day for the first 15 days, followed by 425 $\mathrm{kcal} /$ day for the succeeding 60 days. All subjects lost weight but the reduction in body weight was similar 
in both groups. Total plasma cholesterol, VLDL cholesterol, and LDL cholesterol decreased significantly in both groups after the two periods of caloric restriction, but the percent changes were greater in the soy protein group than in the casein group. Plasma triglyceride was reduced in subjects that received soy protein but not in the group that received casein. These results show that substitution of soy protein can be of benefit in obese patients who need a long-term hypocaloric diet. In a randomized study of parallel-design, Yamashita et al compared the effects of a meat-based diet with a plant-based diet in 36 over- weight or obese women, age $40 \pm 9$ yrs [45]. Both diets were designed to provide similar energy intake but one contained red meat and the other soybeans as the major protein source. After 16 weeks on the diet, subjects in both diet groups lost weight ( $9 \%$ of body weight) and showed similar decreases in plasma total cholesterol, LDL cholesterol, triacylglycerol and leptin levels. Interestingly, there was a significant reduction in the waist-to-hip ratio in both groups of subjects, suggesting that the weight loss induced by both diets was due in part to a decrease in abdominal fat.

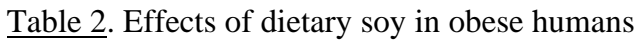

\begin{tabular}{|c|c|c|c|c|}
\hline Disease & Diet and Amount & Duration & Effects & References \\
\hline $\begin{array}{l}\text { Overweight and } \\
\text { mildly obese men } \\
\quad(\mathrm{N}=12)\end{array}$ & $\begin{array}{l}\text { Soydiet with } 28-29 \% \text { of energy as protein } \\
\text { vs pork diet and carbohydrate diet }\end{array}$ & 4 days & $\begin{array}{l}\text { Lower 24-hr energy expenditure with soy than } \\
\text { with pork diet }\end{array}$ & 42 \\
\hline $\begin{array}{l}\text { Obese subjects } \\
\qquad(\mathrm{N}=24)\end{array}$ & $\begin{array}{l}\text { Hypocaloric diet with soy protein vs } \\
\text { hypocaloric diet with casein, } 375 \mathrm{Kcal} / \mathrm{d} \\
\text { for } 15 \text { days, } 426 \mathrm{kcal} / \mathrm{d}\end{array}$ & 60 day & $\begin{array}{l}\text { Decreased BW in both diets but greater reduc- } \\
\text { tions in total cholesterol, VLDL and LDL cho- } \\
\text { lesterol, and triglyceride }\end{array}$ & 43 \\
\hline $\begin{array}{l}\text { Obese women } \\
\qquad(\mathrm{N}=36)\end{array}$ & $\begin{array}{l}\text { Low-energy diet with soybeans vs low } \\
\text { energy diet with lean meat }\end{array}$ & $16 \mathrm{wks}$ & $\begin{array}{l}\text { decrease in BW (9\%) in both diets with similar } \\
\text { reductions in plasma lipid and leptin levels }\end{array}$ & 44 \\
\hline $\begin{array}{l}\text { Obese subjects } \\
\qquad(\mathrm{N}=100)\end{array}$ & $\begin{array}{c}\text { Soy-based meal replacement formula } \\
\text { ( } 240 \mathrm{~g} / \text { day, } 1200 \mathrm{kcal} / \text { day) vs control } \\
\text { diet }\end{array}$ & 12 wks & $\begin{array}{l}\text { Greater weight loss, greater reductions in body } \\
\text { fat mass and total and LDL cholesterol }\end{array}$ & 45 \\
\hline $\begin{array}{l}\text { Pre-obese subjects } \\
\qquad(\mathrm{N}=90)\end{array}$ & $\begin{array}{l}\text { Lifestyle education, high soy protein diet } \\
\text { w or w/o physical activity }\end{array}$ & $6 \mathrm{mos}$ & $\begin{array}{l}\text { All } 3 \text { interventions reduced BMI, greater de- } \\
\text { crease in BW and fat mass with physical activity }\end{array}$ & 46 \\
\hline $\begin{array}{l}\text { Overweight and } \\
\text { obese women } \\
(\mathrm{N}=90)\end{array}$ & $\begin{array}{l}\text { Milk-based meal replacement (MR) vs } \\
\text { soy-based MR in low energy diets }\end{array}$ & 12 wks & $\begin{array}{c}\text { Modest weight loss, greater reductions in total } \\
\text { and LDL cholesterol and triglyceride levels with } \\
\text { soy MR than with milk MR }\end{array}$ & 47 \\
\hline
\end{tabular}

$\mathrm{N}$ = number of subjects; $\mathrm{BW}=$ body weight

Allison et al [46] performed a 12-week randomized controlled trial of a low calorie soy-based meal replacement program in 100 obese subjects. Subjects were randomized to either the meal replacement treatment group ( $240 \mathrm{~g} /$ day, $1200 \mathrm{kcal} /$ day) or control group for a duration of 12 weeks. Subjects treated with the soy-based meal replacement formula lost more weight $(7.0 \mathrm{vs} 2.9 \mathrm{~kg})$ and significantly greater reductions in body fat mass and in total cholesterol and LDL cholesterol than the control subjects. For any given degree of weight loss, the reduction in LDL cholesterol appeared to be greater in the treatment group.

In a randomized controlled trial, Deibert et al. [47] compared the effects of three different interventions containing lifestyle education (LE-G) or a substitutional diet containing high-soy protein low-fat diet with (SD/PA-G) or without (SD-G) a guided physical activity program in 90 pre-obese and obese subjects with a mean body mass index (BMI) of 51.5. Subjects were randomly assigned to one of three interventions for 6 months. All 3 interventions significantly reduced BMI by about $2-3 \mathrm{~kg} / \mathrm{m}^{2}$. However, subjects treated with SD-G and SD/PA-G lost more weight and had a greater decrease in body fat mass than those treated with LE-G. By contrast, no significant differences were observed in lean body mass between the three treatment groups. This study indicated that a high-soy protein and low-fat diet can improve body composition and produce greater losses in body weight and fat mass without losing muscle mass in overweight and obese individuals.

In a 12-week randomized trial of obese subjects, Anderson and Hoie compared the effects of soy- versus milk-based meal replacements (MR) in overweight and obese women (BMI of $27-40 \mathrm{~kg} / \mathrm{m} 2$ ) who consumed low-energy diets (LED). Subjects were randomly assigned to LED provided $1200 \mathrm{kcal} /$ day, with consumption of five soy-based or two milk-based liquid MR for 12 weeks [48]. Subjects who consumed soy-MR had greater weight loss than those who consumed milk-MR ((9.0 \% vs7.9\%) but the difference was not statistically significant. However, there were significantly greater reductions total cholesterol, LDL cholesterol and triglyceride levels with soy-MR than with milk-MR. This study indicated that the use of a soy- based liquid meal replacement in a low-energy diet induced modest weight loss, that was associated with significant reduction in blood lipids.

\section{Mechanisms of actions of soy protein}

The mechanisms whereby soy protein may exert its beneficial effects on obesity are not completely clear. Several lines of evidence suggest that soy protein may favorably affect lipid absorption, insulin resistance, fatty acid metabolism, and other hormonal, cellular, or molecular changes associated with adiposity.

It is well established that soy protein consumption reduces serum total cholesterol, LDL cholesterol, and triglycerides as well as hepatic cholesterol and triglycerides. Studies in animals indicate that soy protein ingestion exerts its lipid-lowering effect by re- 
ducing intestinal cholesterol absorption and increasing fecal bile acid excretion, thereby reducing hepatic cholesterol content and enhancing removal of LDL $(49,50)$. Dietary soy protein has also been shown to directly affect hepatic cholesterol metabolism and LDL receptor activity [51-53]. For example, Lovati and co-workers [51] demonstrated an increased binding of VLDL to liver membranes of hypercholesterolemic rats fed a diet containing soy protein, suggesting altered hepatic metabolism with increased LDL and beta-VLDL removal by hepatocytes. Another study by Lovati et al have shown that soy protein diet consistently increased degradation of LDL by mononuclear cells from patients with hypercholesterolemia, even in the presence of an elevated cholesterol intake [52]. Additional support for an effect of soy protein on LDL receptor activity was provided by Kirk et al. [53] in their studies using the LDL-receptor deficient (LDLr-null) mouse. In this study, significant reductions in plasma concentrations of total cholesterol, LDL-C, and VLDL-C were observed in C57BL/6J (wild type) mice fed soy protein isolate. By contrast, no significant effect of the soy protein isolate on plasma lipids was observed in LDLr-null mice, suggesting that soy isoflavones might reduce lipid levels by increasing LDL receptor activity. Earlier work in humans with normal and elevated serum cholesterol has also shown that dietary soy protein reduces insulin/glucagon ratio, which may contribute to the hypocholesterolemic effect of soy protein [54]. More recently, Gudbrandsen et al have shown that feeding obese Zucker rats with soy protein concentrate enriched with isoflavones (HDI) for 6 weeks reduced fatty liver and decreased the plasma levels of alanine transaminase and aspartate transaminase [55]. These effects were accompanied by increased activities of mitochondrial and peroxisomal beta-oxidation, acetyl-CoA carboxylase, fatty acid synthase and glycerol-3-phosphate acyltransferase in liver, increased plasma triacylglycerol level, and decreased hepatic mRNA level of VLDL receptor. However, the decreased gene expression of VLDL receptor found in the liver was not observed in epididymal fat and skeletal muscle of rats fed HDI, indicating that the liver may be the primary organ responsible for the reduced clearance of triacylglycerol-rich lipoproteins from plasma after HDI feeding. Thus, soy protein appears to exert its cholesterol-lowering action through different mechanisms that modulate cholesterol absorption and metabolism.

There is in-vivo evidence that soy protein may influence lipogenesis in the liver. In studies of rats, Iritani et al have shown that dietary soybean protein reduced the concentrations of triglycerides in plasma and especially in liver [56]. These effects were associated with marked reductions in the activities of hepatic lipogenic enzymes, particularly glucose-6-phosphate dehydrogenase, malic enzyme, fatty acid synthetase, as well as acetyl-CoA carboxylase (ACC) [56], suggesting that soy protein reduces liver triglycerides or fat by partly inhibiting hepatic fatty acid synthesis in the liver. ACC, the rate-limiting enzyme that catalyzes the carboxylation of acetyl-Co A to form malonyl-CoA, is the pivotal enzyme in the biosynthesis of long-chain fatty acids [57]. Recently, dietary SPI has also been shown to reduce the expression of ACCa and ACCb isoforms mRNA and protein contents in the liver of rats [58]. This action of SPI appears to be tissue-specific since the suppressive effect on ACC isoform gene expression was observed only in the liver but not in the heart or kidney. Furthermore, the ratios of phospho-ACCa/ACCa and phopho- $\mathrm{ACCb} / \mathrm{ACCb}$ were unchanged by SPI, suggesting that regulation of ACC by SPI was primarily mediated through alteration of its gene expression rather than phosphorylation or dephosphorylation. A similar reduction of hepatic ACCa mRNA expression by soy protein was also found in another study by Aoki et al [59] in which rats were fed SPI diet. In this study, SPI also reduced the expression of promoter I (PI) specific gene expression of ACCa, suggesting that SPI feeding suppresses ACCa gene expression mainly by regulating PI promoter.

There is also experimental evidence that suggests that soy protein improves insulin resistance and lipid levels by activating peroxisome-proliferator activated receptors (PPARs), which are nuclear transcription factors that regulate the expression of genes involved in glucose homeostasis, lipid metabolism, and fatty acid oxidation $[60,61]$. Mezei et al showed that consumption of high-isoflavone soy protein diet improves glucose tolerance, insulin resistance, and hepatic cholesterol and triglyceride concentrations in obese Zucker rats [60]. In cell culture studies, these investigators further showed that isoflavone-containing soy extracts and individual soy isoflavones increased the gene expression of PPARs, suggesting that the beneficial effects of soy protein on glucose and lipid metabolism may be mediated through PPAR activation. More recently, Morifuji et al [61] demonstrated that soy protein feeding in rats decreased hepatic triacylglycerol levels and epididymal adipose tissue weight. These changes were associated with increased activity and mRNA levels of several skeletal muscle enzymes involved in fatty acid oxidation, including carnitine palmitoyltransferase (CPT1) activity and CPT1, beta-hydroxyacyl-CoA dehydrogenase (HAD), acyl-CoA oxidase, and medium-chain acyl-CoA dehydrogenase. Moreover, PPAR gamma coactivator 1 alpha (PGC1 alpha) PGC1 alpha and PPAR alpha mRNA levels were also found to be elevated, suggesting that soy protein intake stimulates skeletal muscle fatty acid oxidation by activating PPAR pathways leading to reduced accumulation of body fat.

Soy protein may reduce adiposity by modulating the expression of sterol regulatory element binding proteins (SREBPs), a family of transcription factors that controls multiple genes involved in fatty acid and cholesterol synthesis. In obese Zucker fa/fa rats, soy protein feeding was shown to reduce the expression of the hepatic SREBP-1 (the principal regulator of hepatic fatty acid biosynthesis) and its target genes - fatty acid 
synthase (FAS), steroyl-CoA-desaturase- 1 , and delta-5 and delta-6 desaturases [62]. In addition, the soy protein diet also ameliorated fatty liver and markedly reduced hepatic cholesterol and triglyceride content, despite the fact that the rats were severely hyperinsulinemic. These findings suggest that soy protein consumption downregulates hepatic SREBP-1 expression through an insulin-independent mechanism. In contrast to the changes in the liver, PPAR gamma (nuclear hormone receptor involved in normal adipocyte differentiation) mRNA expression in adipose tissue was increased in obese rats fed soy protein. Histological analysis of epididymal adipose tissue from rats fed the soy protein revealed that there were more adipocytes per area but they were smaller in size than those fed casein. Taken together, these findings suggest that soy protein intake may limit adiposity by reducing the number of dysfunctional adipocytes possibly as a result of low lipogenesis. Soy protein may also reduce hepatic lipotoxicity by maintaining the number of functional adipocytes, preventing the transfer of fatty acids to extra adipose tissues.

Another possible mechanism of action of soy protein is via stimulation of adiponectin, a cytokine produced by fat cells that plays a key role in regulating in adipocyte differentiation and secretory function, and in enhancing insulin sensitivity [63-65]. Plasma levels of this hormone are reduced in obesity $[66,67]$. There is one report showing that dietary SPI intake is associated with increased plasma concentration of adiponectin in Wistar rats [68], suggesting that soy protein may modulate adiponectin production.

Which component(s) in soy protein is (are) responsible for its hypolipidemic and antiobesity effects is not entirely clear. Because soy protein contains many bioactive compounds or nutrients that may have multiple mechanisms of actions, it is difficult in nutritional intervention trials to disentangle the effect of any one constituent on lipid or body fat reduction. There are, however, in-vivo and in-vitro studies in which the effects of an isolated component or a single compound of soy protein on lipids have been examined.

Certain polypeptides or subunits of soy protein have been shown to mimic some of the effects of dietary soy protein on food intake and lipid metabolism. For example, in Sprague Dawley rats, oral administration of the soybean $\beta$-conglycinin peptone suppresses food intake and gastric emptying [69]. These effects were attributed in part to an increase in circulating levels of cholecystokinin. Similarly, in rats fed a hypercholesterolemic diet, ingestion of the alpha subunit of the soy 7S globulin (conglycinin) produced substantial reductions in plasma lipids as well as a marked upregulation of liver beta-VLDL receptors [70]. A soybean $\beta$-conglycinin diet was also shown to lower serum triglyceride, glucose, and insulin levels in normal and genetically obese (KK-Ay) mice [71]. These effects were accompanied by reduced hepatic fatty acid synthase activity and increased activities of two enzymes related to fatty acid beta-oxidation and
mRNA of acyl-CoA oxidase levels, as well as increased fecal excretion of tryglycerides, indicating that soy $\beta$-conglycinin reduces serum TG levels by suppression of hepatic fatty acid synthesis, acceleration of beta-oxidation, and/or increased TG fecal excretion [71].

Soyasaponins have been reported to reduce serum cholesterol [72] but their role in fatty acid metabolism is unknown. In a recent study of golden Syrian hamsters, a diet containing group B soyasaponins (with no isoflavones) was shown lower plasma total cholesterol, non-HDL cholesterol, triglycerides, and the ratio of total cholesterol to HDL-cholesterol [73]. These changes were associated with increased fecal excretion of bile acids and neutral sterols, suggesting that group B soyasaponins reduces plasma lipids by a mechanism involving greater excretion of fecal bile acids and neutral sterols. Interestingly, an earlier report showed that oral administration of total soyasaponins was also found to prevent the development of obesity and hyperinsulinemia induced by gold thioglucose injection in mice [74].

Phospholipids present in soy protein may be partly responsible for its antilipidemic effects. Short-term feeding with a diet containing soybean phospholipids for 3 days was shown to markedly reduce the activities of hepatic fatty acid synthetase, malic enzyme, glucose 6-phosphate dehydrogenase and pyruvate kinase in rats [75]. Compared to a fat-free diet or a diet containing soybean oil, the diet containing soybean phospholipids also markedly decreased the hepatic mRNA levels of enzymes in fatty acid synthesis. A greater reduction of serum cholesterol as well as total lipid and cholesterol concentrations in liver was also observed when rats were fed a soy protein peptic hydrolysate with bound phospholipids, compared to soy protein diet alone or soy protein hydrolysate [76].

Part of the antiobesity effect of soy protein may be due to the presence of the isoflavones, since soy isoflavones have been shown to decrease fat accumulation in certain fat depots in some animal models of obesity [77-79]. Additionally, work by Mezei et al [60] has shown that consumption of a high isoflavone-containing soy diet improves glucose tolerance and reduces liver triglyceride and cholesterol concentrations obese Zucker rats. Moreover, cell culture studies showed that isoflavone-containing soy extracts and individual soy isoflavones, genistein and daidzein upregulate PPARalpha and PPARgamme-mediated gene expression. Exposure to soy isoflavones was also shown increase the expressions of the mature form of SREBP-2 and SREBP-regulated genes in HepG2 cells [80]. Furthermore, exposure to soy isoflavones also increased HMG CoA reductase protein levels and HMG CoA synthase mRNA levels and increased both HMG CoA synthase and LDL receptor promoter activity, indicating that isoflavones may also regulate the genes involved in cholesterol biosynthesis and homeostasis.

Interestingly, in a recent study of agouti viable 
yellow ( $\left.A^{v y}\right)$ mice, a genetic model that develops hyperinsulinemia, obesity, type 2 diabetes, and yellow fur, it was shown that dietary genistein supplementation of female mice during gestation at levels comparable with those received by humans consuming high-soy diets, resulted in a shift in coat color of heterozygous mice and protected offsprings from developing obesity [81]. These marked phenotypic changes induced by dietary genistein appear to be mediated by increased DNA methylation in tissues during early embryonic development that persisted into adulthood.

Thus, certain polypeptides (such as 7S globulin or conglycinin), soyasaponins, phospholipids, and isoflavones (genistein and daidzein) present in soybean appear to have complimentary actions on fatty acid and cholesterol metabolism, which may contribute to the overall beneficial effects of soy protein in obesity and associated lipid abnormalities.

\section{Soy protein allergy}

Soybean has long been implicated as a possible cause of food allergy [82] and is cited as one of the 8 most common allergenic foods. This "group of 8 " includes milk, eggs, fish, crustacea, wheat, peanuts, tree nuts, and soy, accounting for about $90 \%$ of food allergies [83]. Soy protein allergy occurs only in a minority of children with food allergies and is relatively uncommon in adults [83-85]. For example, a meta-analysis of 17 different studies of allergen reactivity in infants and children showed that soy allergy occurs in about $3-4 \%$ of subjects compared to $25 \%$ for allergy to cow's milk [84]. There are also reports that soy protein has a lower allergenic potential when compared with other major food proteins [85]. In addition, studies comparing dose-response relationships of different food allergens for triggering allergic symptoms also demonstrate a much higher protein concentration threshold for soy protein than other food proteins [86]. In view of the lower allergic potential of soy protein, soy milk formulas have been widely used for the management of food allergy in infants and children.

The component in soy protein responsible for allergic reactions is not completely certain but several potential soy protein allergens have been identified in a number of studies in soybean-sensitive patients These include include b-conglycinin, glycinin, soy vacuolar protein, Kunitz trypsin inhibitor, and other proteins [83,87-89]. Awazuhara et al detected IgE- and IgG4-binding proteins in soybean by immunoblotting with sera from 30 soybean-sensitive patients [88]. Ten proteins were detected as IgE-binding proteins and 8 proteins as IgG4-binding proteins, with high IgE detection rate and specificity. Among the IgE-binding proteins, the proteins with molecular weights of 20,000 and 58,000 were found to be in the whey fraction, and 26,000 and 31,000 were in the globulin fraction. Five proteins were suggested as the major allergens in the IgE-mediated reaction where as IgG4-binding proteins might act anaphylactically in patients with soybean allergy. Ogawa et al also showed that at least 15 soy protein allergens were recognized by sera of soybean-sensitive patients [89]. The three major the allergenic soy proteins found in these patients were Gly m Bd 60 K, Gly m Bd 30 K, and Gly $\mathrm{m} \mathrm{Bd} 28 \mathrm{~K}$. It has been shown that certain soy protein products can be made hypoallergenic by chemical treatment or by genetic modification by transgenic techniques $[90,91]$. For now, the only treatment available for soy protein allergy is avoidance of soy-based protein products.

\section{Summary and Conclusions}

In conclusion, an increasing body of evidence from nutritional intervention studies in animals and humans indicates that dietary soy protein has beneficial effects on obesity. Consumption of soy protein can favorably affect satiety and reduce excess body fat in obese animals and humans. Soy protein ingestion also improves insulin resistance, the hallmark of obesity. Dietary soy protein and some of its constituents also reduce plasma lipids and fat accumulation in liver and adipose tissue, which may reduce the risks of atherosclerosis and lipotoxicity and possibly other obesity-related complications. Several potential mechanisms whereby soy protein or its constituents may improve insulin resistance and lower body fat and blood lipids have been discussed and include a wide spectrum of biochemical and molecular activities that favorably affect energy balance and fat metabolism. Furthermore, in animal models of obesity, dietary soy protein and isoflavones appear to modulate the expression of nuclear transcription factors, namely PPARs and SREBPs, which are the principal regulators of fatty acid metabolism and cholesterol homeostasis. Thus far, clinical studies that have been conducted in obese humans are few and limited by the relatively short duration of the dietary interventions and the inclusion a small number of subjects. Ingestion of soy protein, like any food that contains protein, has to potential to cause an allergic reaction and, therefore, should be avoided in high-risk individuals with food allergies. Long-term prospective randomized trials involving a large number of obese subjects are needed to confirm whether soy protein provides long-term safety and benefits in humans with obesity.

\section{Conflict of interest}

The authors have declared that no conflict of interest exists.

\section{References}

1. WHO. Joint WHO/FAO Expert Consultation on diet, nutrition and the prevention of chronic diseases: Report of a joint WHO/FAO expert consultation. Geneva, Switzerland: WHO, 2003.

2. Ogden CL, Carroll MD, Curtin LR, McDowell MA, Tabak CJ, Flegal KM. Prevalence of overweight and obesity in the United States, 1999-2004. JAMA 2007; 295: 1549-1555.

3. Hedley AA, Ogden CL, Johnson CL, Carroll MD, Curtin LR, Flegal KM. Prevalence of overweight and obesity among US children, adolescents, and adults, 1999-2002. JAMA 2004; 291: 2847-2850.

4. Wang Y, Monteiro C, Popkin BM. Trends of overweight in chil- 
dren and adolescents in the United states, Brazil, China, and Russia. Am J Clin Nutr 2002; 75: 971-977.

5. Troiano RP, Frongillo EA Jr, Sobal J, Levitsky DA. The relationship between body weight and mortality: a quantitative analysis of combined information from existing studies. Int J Obes 1996; 20: 63-75.

6. Flegal KM, Graubard BI, Williamson DF, Gail MH. Excess deaths associated with underweight, overweight, and obesity. JAMA 2005; 293: 861-1867.

7. Popkin BM. The nutrition transition and its health implications in lower income countries. Public Health Nutr 1988; 1: 5-21.

8. Uauy R, Dias E. Consequences of food energy excess and positive energy balance. Public Health Nutr 2005; 8: 1077-1099.

9. Grundy SM. Metabolic syndrome: therapeutic considerations. Handb Exp Pharmacol 2005; 170: 107-133.

10. Boden G, Shulman GI. Free fatty acids in obesity and type 2 diabetes: defining their role in the development of insulin resistance and beta-cell dysfunction. Eur J Clin Invest 2002; 32(Suppl 3): 14-23.

11. Zhou YT, Grayburn P, Karim A, et al. Lipotoxic heart disease in obese rats: implications for human obesity. Proc Natl Acad Sci USA 2000; 97: 1784-1789.

12. Schaffer JE. Lipotoxicity: when tissues overeat. Curr Opin Lipidol 2003; 14: 281-287.

13. Montani J, Carroll JF, Dwyer TM, Antic V, Yang Z, Dulloo AG. Ectopic fat storage in heart, blood vessels and kidneys in the pathogenesis of cardiovascular diseases. Int J Obes 2004; 28:558-565.

14. Anderson GH, Moore SE. Dietary proteins in the regulation of food intake and body weight in humans. J Nutr 2004; 134: 974S-979S.

15. Skov AR, Toubro S, Ronn B, Holm L, Astrup A. Randomized trial on protein vs carbohydrate in ad libitum fat reduced diet for the treatment of obesity. Int J Obes Relat Metab Disord 1999; 23: 528-536.

16. Baba NH, Sawaya S, Torbay N, Habbal Z, Azar S, Hashim SA. High protein vs high carbohydrate hypoenergetic diet for the treatment of obese hyperinsulinemic subjects. Int J Obes Relat Metab Disord 1999; 23:1202-1206.

17. Weigle DS, Breen PA, Matthys CC, Callahan HS, Meeuws KE, Burden VR, Purnell JQ. A high-protein diet induces sustained reductions in appetite, ad libitum caloric intake, and body weight despite compensatory changes in diurnal plasma leptin and ghrelin concentrations. Am J Clin Nutr 2005; 82:41-48.

18. Batterham RL, Heffron H, Kapoor S, Chivers JE, Herzog H, Le Roux CW, Thomas EL, Bell JD, Withers DJ. Critical role for peptide $Y Y$ in protein-mediated satiation and body-weight regulation. Cell Metab 2006; 4:223-233.

19. Hurley C, Richard D, Deshaies Y, Jacques H. Soy protein isolate in the presence of cornstarch reduces body fat gain in rats. Can J Physiol Pharmacol 1998; 76: 1000-10007.

20. Lavigne C, Marette A, Jacques H. Cod and soy proteins compared with casein improve glucose tolerance and insulin sensitivity in rats. Am J Physiol Endocrinol Metab 2000; 278: E491-E500.

21. Davis J, Steinle J, Higginbotham DA, Oitker J, Peterson RG, Banz WJ. Soy protein influences insulin sensitivity and cardiovascular risk in male lean SHHF rats. Horm Metab Res 2005;37: 309-315.

22. Anderson GH, Tecimer SN, Shah D, Zafar TN. Protein source, quantity, and time of consumption determine the effect of protein on short-term food intake in young men. J Nutr 2004; 134: 3011-3015.

23. Lang V, Belisle F, Oppert JM, Craplet C, Bornet FRJ, Slama G, Guy-Grand B. Satiating effect of proteins in healthy subjects: comparison of egg albumin, casein, gelatin, soy protein, pea protein, and wheat gluten. Am J Clin Nutr 1998; 67: 1197-1204.
24. Grieshop CM, Kadzere CT, Clapper GM, Flickinger EA, Bauer LL, Frazier RL, Fahey GC Jr. Chemical and nutritional characteristics of United States soybeans and soybean meals. J Agric Food Chem 2003; 51: 7684-7691.

25. Grieshop CM, Fahey GC Jr. Comparison of quality characteristics of soybeans from Brazil, China, and the United States. J Agric Food Chem 2001; 49: 2669-2673.

26. Garcia MC, Torre M, Marina ML, Laborda F. Composition and characterization of soybean and related products. Crit Rev Food Sci Nutr 1997; 37: 361-391.

27. Haytowitz DB, Mathews RH. Legumes and legume products. Washington, DC: US Department of Agriculture. 1986.

28. Young VR. Soy protein in relation to human protein and amino acid nutrition. J Am Diet Assoc 1991; 91: 828-835.

29. Gudbrandsen OA, Wergedahl H, Liaset B, Espe M, Berge RK. Dietary proteins with high isoflavone content or low methionine-glycine and lysine-arginine ratios are hypocholesterolemic and lower the plasma homocysteine level in male Zucker fa/fa rats. Br J Nutr 2005; 94: 321-330.

30. Fang N, Yu S, Badger TM. Comprehensive phytochemical profile of soy protein isolate. J Agric Food Chem 2004; 52:4012-4020.

31. Berhow MA, Kong SB, Vermillion KE, Duval SM. Complete quantification of group $\mathrm{A}$ and group $\mathrm{B}$ soyasaponins in soybeans. J Agric Food Chem 2006; 54: 2035-2044.

32. Hubert J, Berger M, Dayde J. Use of simplified HPLC-UV analysis for soyasaponin B determination: study of saponin and isoflavones variability in soybean cultivars and soy-based health food products. J Agric Food Chem 2005; 53: 3923-3930.

33. Wang HJ, Murphy PA. Isoflavone content in commercial soybean foods. J Agric Food Chem 1994; 42: 1666-1673.

34. Wang H-J, Murphy PA. Isoflavone composition of American and Japanese soybean in Iowa: effects of variety, crop year, and location. J Agric Food Chem 1994; 42: 1674-1677.

35. [Internet] US Department of Agriculture Nutrient Data Laboratory. USDA-Iowa State University database on the isoflavones contents of foods. Accessed 28 August 2002. http://www.nal.usda.gov/fnic/foodcomp/data/isoflav.html.

36. Caldwell CR, Britz SJ, Mirecki RM. Effect of temperature, elevated carbon dioxide, and drought during seed development on the isoflavone content of dwarf soybean [Glycine max (L.) Merrill] grown in controlled environments. J Agric Food Chem 2005; 53: 1125-1129.

37. Iritani N, Hosomi H, Fukuda H, Tada K, Ikeda H. Soybean protein suppresses hepatic lipogenic enzyme gene expression in Wistar fatty rats. J Nutr 1996; 126: 380-388.

38. Iritani N, Sugimoto T, Fukuda H, Komiya M, Ikeda H. Dietary soybean protein increases insulin receptor gene expression in male Wistar fatty rats when dietary polyunsaturated fatty acid level is low. J Nutr 1997; 127: 1077-1083.

39. Aoyama T, Fukui K, Takamatsu K, Hashimoto Y,Yamamoto T. Soy protein isolate and its hydrolysate reduce body fat of dietary obese rats and genetically obese mice (yellow KK). Nutrition 2000; 16: 349-354.

40. Aoyama T, Fukui K, Nakamori T, Hashimoto Y, Yamamoto T, Takamatsu K, Sugano M. Effect of soy and milk whey protein isolates and their hydrolysates on weight reduction in genetically obese mice. Biosci Biotechnol Biochem 2000; 64: 2594-2600.

41. Nagasawa A, Fukui K Funahashi T, Maeda N, Shmomura I, Kihara S, Waki M, Takamatsu K, Matsuzawa Y. Effects of soy protein diet on the expression of adipose genes and plasma adiponectin. Horm Metab Res 2002; 34:635-639.

42. Johnson PR, Stern JS, Horwitz BA, Harris RE Jr, Greene SF. Longevity in obese and lean male and female rats of the Zucker strain: prevention of hyperphagia. . Am J Clin Nutr 1997; 66: 890-893.

43. Mikkelsen PB, Toubro S, Astrup A. Effects of fat-reduced diets on 24-h energy expenditure: comparisons between animal pro- 
tein, vegetable protein, and carbohydrate. Am J Clin Nutr 2000; 72: 1135-1141.

44. Bosello O, Cominacini L, Zocca I Garbin U, Compri R, Davoli A, Brunetti L. Short- and long-term effects of hypocaloric diets containing proteins of different sources on plasma lipids and apoproteins of obese subjects. Ann Nutr Metab 1998; 32: 206-214.

45. Yamashita T, Sasahara T, Pomeroy SE, Collier G, Nestel PJ. Arterial compliance, blood pressure, plasma leptin, and plasma lipids in women are improved with weight reduction equally with a meat based-diet and a plant-based diet. Metabolism 1998; 47: 1308-1314.

46. Allison DB, Gadbury G, Schwartz LG, Murugeasn R, Kraker JL, Heshka S, Fontaine KR, Heimsfield SB. A novel soy-based meal replacement formula for weight loss among obese individuals: a randomized controlled clinical trial. Eur J Clin Nutr 2003, 57:514-522.

47. Deibert P, Konig D, Schmidt-Trucksaess A, Zaenker KS, Frey I, Landmann U, Berg A. Weight loss without losing muscle mass in pre-obese and obese subjects induced by high-soy-protein diet. Int J Obes Relat Disord 2004, 28: 1349-1352.

48. Anderson JW, Hoie LH. Weight loss and lipid changes with low-energy diets: comparator study of milk-based versus soy-based liquid meal replacement interventions. J Am Coll Nutr 2005, 24:210-216.

49. Greaves KA, Wilson MD, Rudel LL, Williams JK, Wagner JD. Consumption of soy protein reduces cholesterol absorption compared to casein protein alone or supplemented with an isoflavone extract or conjugated equine estrogen in ovariectomized cynomolgous monkeys. J Nutr 2000; 130: 820-826.

50. Wright SM, Salter AM. Effects of soy protein on plasma cholesterol and bile acid excretion in hamsters. Comp Biochem Physiol 1998; 119B: 247-254.

51. Lovati MR, Allievi L, Sirtori CR. Accelerated early catabolism of very low density lipoprotein in rats after dietary soy protein. Atherosclerosis 1985; 56: 243-246.

52. Lovati MR, Manzoni C, Canaveri A, et al. Soybean protein diet increases low density receptor activity in mononuclear cells from hypercholesterolemic patients. J Clin Invest 1987; 80: 1498-1502.

53. Kirk EA, Sutherland P, Wang SA, Chait A, Leboeuf RC. Dietary isoflavones reduce plasma cholesterol and atherosclerosis in C57BL/ 6 mice but not LDL receptor-deficient mice. J Nutr 1998; 128: 954-959.

54. Hubbard R, Kosch CL, Sanchez A, Sabate J, Berk L, Shavlick G. Effect of dietary protein on serum insulin and glucagon levels in hyper- and normocholesterolemic men. Atherosclerosis 1989; 76 : 55-61.

55. Gudbrandsen OA, Wergedahl H, Mork S, Liaset B, Espe M, Berge RK. Dietary soya protein concentrate enriched with isoflavones reduced fatty liver, increased hepatic fatty acid oxidation and decreased the hepatic mRNA level of VLDL receptor in obese Zucker rats. Br J Nutr 2006; 96:249-257.

56.. Iritani N, Nagashima K, Fukuda H, Katsurada A, Tanaka T. Effects of dietary proteins on lipogenic enzymes in rat liver. J Nutr 1986;116: 190-197.

57. Dyck JR, Berthiaume LG, Thomas PD, Kantor PF, Barr AJ, Barr R, Singh D, Hopkins TA, Voilley N, Prentki M, Lopaschuk GD. Characterization of rat liver malonyl-CoA decarboxylase and the study of its role in regulating fatty acid metabolism. Biochem J 2000; 350: 599-608.

58. Xiao CW, Wood C, Huang W, L'Abbe MR, Gilani GS, Cooke GM, Curran I. Tissue-specific regulation of acetyl-Co A carboxylase gene expression by dietary soya protein intake in rats. Br J Nutr 2006, 95:1048-1054.

59. Aoki H, Kimura K, Igarashi K, Takenaka A. Soy protein suppresses gene expression of acetyl-CoA carboxylase alpha from promoter PI in rat liver. Biosci Biotechnol Biochem 2006, 70:843-849.

60. Mezei O, Banz WJ, Steger RW, Peluso MR, Winters TA, Shay N. Soy isoflavones exert antidiabetic and hypolipidemic effects through the PPAR pathways in obese Zucker rats and murine RAW 264.7 cells. J Nutr 2003;133:1238-1243.

61. Morifuji M, Sanbongi C, Sugiura K. Dietary soya protein intake and exercise training have an additive effect on skeletal muscle fatty acid oxidation enzyme activities and mRNA levels in rats.Br J Nutr 2006; 96:469-475.

62. Tovar AR, Torre-Villalvazo I, Ochoa M, Elias AL, Ortiz V, Aguilar-Salinas CA, Torres N. Soy protein reduces hepatic lipotoxicity in hyperinsulinemic obese Zucker fa/fa rats. J Lipid Res 2005; 46: 1823-1832.

63. Lihn AS, Pedersen SB, Richelsen B. Adiponectin: action, regulation and association to insulin sensitivity. Obes Rev 2005; 6:13-21.

64. Fu Y, Luo N, Klein RL, Garvey WT. Adiponectin promotes adipocyte differentiation, insulin sensitivity, and lipid accumulation. J Lipid Res 2005; 46:1369-1379.

65. Dietze-Schroeder D, Sell H, Uhlig M, Koenen M, Eckel J. Autocrine action of adiponectin on human fat cells prevents the release of insulin resistance-inducing factors. Diabetes 2005; 54: 2003-2011.

66. Arita Y, Kihara S, Ouchi N, Takahashi M, Maeda K, Miyagawa J, Hotta K, Shimomura I, Nakamura T, Miyaoka K, Kuriyama H, Nishida M, Yamashita S, Okubo K, Matsubara K, Muraguchi M, Ohmoto Y, Funahashi T, Matsuzawa Y. Paradoxical decrease of an adipose-specific protein, adiponectin, in obesity. Biochem Biophys Res Commun 1999; 257: 79-83.

67. Weyer C, Funahashi T, Tanaka S, Hotta K, Matsuzawa Y, Pratley RE, Tataranni PA. Hypoadiponectinemia in obesity and type 2 diabetes: close association with insulin resistance and hyperinsulinemia. J Clin Endocrinol Metab 2001;86:1930-1935.

68. Nagasawa A, Fukui K, Kojima M, Kishida K, Maeda N, Nagaretani $\mathrm{H}$, Hibuse T, Nishizawa H, Kihara S, Waki M, Takamatsu K, Funahashi T, Matsuzawa Y. Divergent effects of soy protein diet on the expression of adipocytokines. Biochem Biophys Res Commun 2003; 311: 909-914.

69. Nishi T, Hara H, Tomita F. Soybean beta-conglycinin peptone suppresses food intake and gastric emptying by increasing plasma cholecystokinin levels in rats. J Nutr 2003; 133: 352-357.

70. Duranti M, Lovati MR, Dani V, Barbiroli A, Scarafoni A, Castiglioni S, Ponzone C, Morazzoni P. The alpha' subunit from soybean $7 \mathrm{~S}$ globulin lowers plasma lipids and upregulates liver beta-VLDL receptors in rats fed a hypercholesterolemic diet. J Nutr 2004;134: 1334-1339.

71. Moriyama T, Kishimoto K, Nagai K, Urade R, Ogawa T, Utsumi S, maruyama N, Maebuchi M. Soybean beta-conglycinin diet suppresses serum triglyceride levels in normal and genetically obese mice by induction of beta-oxidation, downregulation of fatty acid synthase, and inhibition of triglyceride absorption. Biosci Biotechnol Biochem 2004; 68: 352-359.

72. Oakenfull DG, Topping DL, Illman RJ, Fenwick DE. Prevention of dietary hypercholesterolaemia in the rat by soya bean and quillaja saponins. Nutr Rep Int 1984; 29:1039-1041.

73. Lee S-O, Simons AL, Murphy PA, Hendrich S. Soyasaponins lowered plasma cholesterol and increased fecal bile acids in female golden Syrian hamsters. Exptl Biol Med 2005; 230: 472-478.

74. Kawano-Takahashi Y, Ohminami H, Okuda H, Kitagawa I, Yoshikawa M, arichi S, Hayashi T. Effect of soya saponins on gold thioglucose (GTG)-induced obesity in mice. Int $J$ Obes 1986;10:293-302.

75. Rouyer IA, Takhashi Y, Ide T. Dietary phospholipid-dependent reductions in gene expression and activity of liver enzymes in fatty acid synthesis in fasted-refed rats. J Nutr Sci Vitaminol (Tokyo) 1999; 45:287-302. 
76. Nagaoka S, Miwa K, Eto M, Kuzuya Y, Hori G, Yamamoto K. Soy protein peptic hydrolysate with bound phospholipids decreases micellar solubility and cholesterol absorption in rats and caco-2 cells. J Nutr 1999;129:1725-1730.

77. Ali AA, Velasquez MT, Hansen CT, Mohamed AI, Bhathena SJ. Effects of soybean isoflavones, probiotics, and their interactions on lipid metabolism and endocrine system in an animal model of obesity and diabetes. J Nutr Biochem 2004;15: 583-590.

78. Banz WJ, Davis J, Peterson R, Iqbal MJ. Gene expression and adiposity are modified by soy protein in male Zucker diabetic fatty rats. Obes Res 2004; 12: 1907-1913.

79. Manzoni MS, Rossi EA, Carlos IZ, Vendramini RC, Duarte AC, Damaso AR. Fermented soy product supplemented with isoflavones affected fat depots in juvenile rats. Nutrition 2005; 21: 1018-1024.

80. Mullen E, Brown RM, Osborne TF, Shay NF. Soy isoflavones affect sterol regulatory element binding proteins (SREBPs) and SREBP-regulated genes in HepG2 cells. J Nutr 2004; 134: 2942-2947.

81. Dolinoy DC, Weidman JR, Waterland RA, Jirtle RL. Maternal genistein alters coat color and protects Avy mouse offspring from obesity by modifying the fetal epigenome. Environ Health Perspect 2006; 114: 567-572.

82. Duke WW. Soybean as a possible important source of allergy. J Allergy 1934; 5:300-302.

83. Cordle CT. Soy protein allergy: incidence and relative severity. J Nutr 2004; 134:1213S-1219S.

84. Cantani A, Lucenti P. Natural history of soy allergy and/or intolerance in children, and clinical use of soy-protein formulas. Pediatr Allergy Immunol 1997; 8:59-74.

85. Zeiger RS, Sampson HA, Bock SA, Burks AW, Harden K, Noone S, Martin D, Leung S, Wilson G. Soy allergy in infants and children with IgE-associated cow's milk allergy. J Pediatr 1999; 134:614-622.

86. Bindslev-Jensen C, Briggs D, Osterballe M. Can we determine the threshold level for allergenic foods by statistical analysis of published data in the literature? Allergy 2002; 57:741-746.

87. Ogawa T, Bando N, Tsuji H, Nishikawa K, Kitamura K. Alpha-subunit of beta-conglycinin, an allergenic protein recognized by $\operatorname{IgE}$ antibodies of soybean-sensitive patients with atopic dermatitis. Biosci Biotechnol Biochem 1995; 59: 831-833.

88. Awazuhara H, Kawai H. \& Maruchi N. Major allergens in soybean and clinical significance of IgG4 antibodies investigated by IgE- and IgG4-immunoblotting with sera from soybean-sensitive patients. Clin Exp Allergy 1997; 27:325-332.

89. Ogawa T, Samoto M, Takahashi K. Soybean allergens and hypoallergenic soybean products. J Nutr Sci Vitaminol 2000; 46:271-279.

90. Franck P, Moneret Vautrin DA, Dousset B, Kanny G, Nabet P, Guenard-Bilbaut L, Parisot L. The allergenicity of soybean-based products is modified by food technologies. Int Arch Allergy Immunol 2002; 128:212-219.

91. Herman EM, Helm RM, Jung R, Kinney AJ. Genetic modification removes an immunodominant allergen from soybean. Plant Physiol 2003; 132:36-43. 